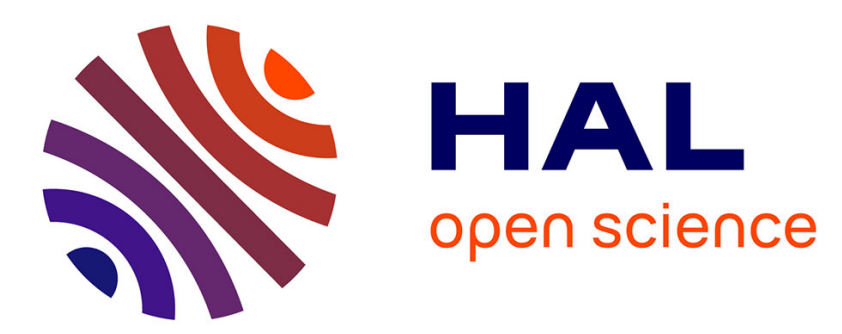

\title{
Stimulation of gonadotropin secretion by intraventricular injection of hypothalamic extracts in the goldfish, Carassius auratus
}

\author{
L.W. Crim, R.E. Peter, Roland Billard
}

\section{- To cite this version:}

L.W. Crim, R.E. Peter, Roland Billard. Stimulation of gonadotropin secretion by intraventricular injection of hypothalamic extracts in the goldfish, Carassius auratus. General and Comparative Endocrinology, 1976, 30 (1), pp.77-82 . 10.1016/0016-6480(76)90068-X . hal-01600632

\section{HAL Id: hal-01600632 \\ https://hal.science/hal-01600632}

Submitted on 2 Jun 2020

HAL is a multi-disciplinary open access archive for the deposit and dissemination of scientific research documents, whether they are published or not. The documents may come from teaching and research institutions in France or abroad, or from public or private research centers.
L'archive ouverte pluridisciplinaire HAL, est destinée au dépôt et à la diffusion de documents scientifiques de niveau recherche, publiés ou non, émanant des établissements d'enseignement et de recherche français ou étrangers, des laboratoires publics ou privés. 


\title{
Stimulation of Gonadotropin Secretion by Intraventricular Injection of Hypothalamic Extracts in the Goldfish, Carassius auratus ${ }^{1}$
}

\author{
L. W. Crim, ${ }^{2}$ R. E. Peter, ANd R. Billard ${ }^{3}$ \\ Department of Zoology, University of Alberta, Edmonton, Alberta, Canada T6G 2E9
}

Accepted April 8, 1976

\begin{abstract}
Goldfish serum gonadotropin (GTH) concentrations were determined by radioimmunoassay $20 \mathrm{~min}$ after injection of goldfish brain extracts or synthetic luteinizing hormone-releasing hormone (LH-RH) into the third ventricle in the ventrobasal hypothalamic region. Extracts of the cerebellum and medulla were ineffective. Synthetic LH-RH, and extract of the lateral hypothalamus each significantly increased plasma GTH levels. The results indicate that the hypothalamus of the sexually mature female goldfish contains gonadotropin releasing hormone activity, and that releasing hormone is effective when administered via the intrahypothalamic route.
\end{abstract}

Direct evidence for the presence of gonadotropin releasing hormone (GRH) in fish hypothalamic tissue is very limited. Crude extracts of carp and trout hypothalamus stimulate release of LH from the sheep pituitary in vitro (Breton et al., 1972). Gonadotropin secretion by carp pituitaries in vitro is increased by extracts of the carp hypothalamus (Breton et al., 1975). The presence of GRH activity in carp hypothalamic extracts given intravenously (iv) to the carp (Breton and Weil, 1973; Weil et al., 1975) provides in vivo evidence in this regard. It has also been shown that synthetic luteinizing hormone-releasing hormone (LH-RH) given iv stimulates gonadotropin secretion in carp (Breton and Weil, 1973; Weil et al., 1975) and trout (Crim and Cluett, 1974). To date, no studies of other brain tissues are available to

1 Supported by National Research Council of Canada Grant A6371 to the second author.

2 Permanent address: Marine Sciences Research Laboratory, Memorial University of Newfoundland, St. John's, Newfoundland, Canada A1C 5S7.

${ }^{3}$ Permanent address: Institut National de la Recherche Agronomique, Laboratoire de Physiologie des Poissons, 78350 Jouy en Josas, France. suggest that GRH activity is specific to the hypothalamus in teleosts.

The purpose of the present investigation was to determine the presence and the distribution of releasing hormone activity in selected areas of the teleost brain. Since in rats intraventricular $\mathrm{LH}-\mathrm{RH}$ treatment is reported to be more effective than the intravenous method, plasma gonadotropin levels in the goldfish were studied following infusion of synthetic LH-RH or various brain tissue extracts directly into the third ventricle of the brain.

\section{MATERIALS AND METHODS}

Goldfish, common or comet variety, used in the study were purchased in April 1975 from Grassyfork Fisheries Co., Inc., Martinsville, Ind. Prior to use in the experiments the fish were held for about 70 days on a simulated natural photoperiod at $10-14^{\circ}$ in $1500-$ liter flow-through aquaria. For the experiments the fish were transferred to 96-liter aquaria at $12-14.5^{\circ}$ and a $16 \mathrm{hr}$ light $-8 \mathrm{hr}$ dark photoperiod. The fish were acclimated to the experimental conditions for about 14 days prior to use.

\section{Experimental Protocol}

A total of 13 sexually mature females weighing 52.3 $\mathrm{g}(\mathrm{SD}=6.0)$ were selected for the experiment. Each fish was identified by a fin clip. A cannula was 
stereotaxically placed in the third ventricle at a position just dorsal to the pituitary stalk according to the technique of Peter (1970) as modified by Peter and Gill (1975). The cannula consisted of a length of 30gauge stainless steel tubing, with an attached anchoring device, as described by Peter and Billard (1976). Screws were anchored in the skull, and the cannula was fixed in place with dental cement as described by Peter and Billard (1976). The cannula was capped by a short piece of PE 20 tubing and sealed at one end before returning the fish to the aquarium.

At 7 and 9 days postoperative the fish were caught by hand and removed to anesthetic solution (tricaine methanesulfonate, 1:1000 dilution). After just ceasing opercular movements in the anesthetic solution, each fish was removed to lie on a dampened towel. The cannula cap was removed and, using a 5- or 10- $\mu$ l Hamilton syringe fitted with a short piece of PE 20 tubing, a volume of $2.2 \mu \mathrm{l}$ of physiological solution (PS) or brain extract dissolved in PS was injected into the cannula. Since the dead space of the cannula was $0.2 \mu \mathrm{l}$, the total volume injected into the brain was 2.0 $\mu 1$. Following injection, the cannula was recapped, and the fish was returned to the aquarium. At $20 \mathrm{~min}$ following the injection, the fish was anesthetized again and a blood sample of about $0.3 \mathrm{ml}$ was taken from the caudal vasculature with a 1-cc disposable syringe fitted with a 25 -gauge $5 / 8$-in. (15.5-mm) needle. After taking the blood sample, $0.2 \mu \mathrm{l}$ of PS was injected into the cannula to flush out any brain extract material. The injections and sampling were done between 6 and $8 \mathrm{hr}$ after the lights came on in each case. The blood samples were stored over chipped ice for 1-2 hr prior to centrifugation at $2400 \mathrm{rpm}$ for $20 \mathrm{~min}$. Serum was pipetted into micro-test tubes, frozen over dry ice, and stored at $-20^{\circ}$ until analysis. The data from both usages of the cannulated fish were pooled for statistical analysis by Student's $t$ test.

\section{Brain Extracts}

Brain tissues for extraction were taken from 15 sexually mature female goldfish weighing $61.9 \mathrm{~g}$ (SD $=5.3$ ), and with a gonosomatic index of $15.07(\mathrm{SD}=$ 5.4). The fish were anesthetized, and the brains were quickly removed. The hypothalamus of each was cut away from the rest of the brain, and the lateral lobes were separated from the medial lobe. The cerebellum and medulla were each cut away from the rest of the brain. The pieces were frozen over dry ice immediately after dissection. The respective brain pieces of the 15 donor fish were pooled (lateral lobes of hypothalamus, $98.8 \mathrm{mg}$; medial lobe of hypothalamus, $53.2 \mathrm{mg}$; cerebellum, $141.3 \mathrm{mg}$; medulla, 211.4 $\mathrm{mg}$ ) and stored over dry ice until extraction.

The pooled tissue fragments were homogenized in $0.5 \mathrm{ml}$ of cold $0.1 \mathrm{~N} \mathrm{HCl}$ with a glass tissue grinder. A volume of $50 \mu \mathrm{l}$ of the extract was taken for gonado- tropin radioimmunoassay (equivalent to the tissue fragments from 1.5 animals). The remaining extract was then rinsed into a centrifuge tube with an additional $0.5 \mathrm{ml}$ of $0.1 \mathrm{~N} \mathrm{HCl}$ and centrifuged at 10,000 rpm for $10 \mathrm{~min}$ at $2^{\circ}$. The supernatant was pipetted into a $120 \times 18 \mathrm{~mm}$ tapered test tube, the $\mathrm{pH}$ was adjusted to 6 with $1 \mathrm{~N} \mathrm{NaOH}$, and frozen by immersing the tube in an acetone-dry ice bath. The extract was lyophilized, and the dried extract was twice washed down into the bottom of the tube with distilled water (DW), frozen, and lyophilized to concentrate it into the bottom of the tube. The dry residue was resuspended in $200 \mu \mathrm{l}$ of DW and centrifuged at $2500 \mathrm{rpm}$ for $10 \mathrm{~min}$ at $2^{\circ}$. The supernatant was lyophilized, and the residue was finally suspended in $30 \mu \mathrm{l}$ of PS and centrifuged at $2500 \mathrm{rpm}$ for $10 \mathrm{~min}$; and the supernatant was used for injection. In the 2.0- $\mu$ l injection volume there was the equivalent of 0.9 fragments of brain tissue.

Synthetic luteinizing hormone-releasing hormone diacetate dihydrate (Lot 208068, Spectrum Medical Industries Inc., Los Angeles, Calif.) was dissolved in PS for a final concentration of $250 \mathrm{ng} / 2.0 \mu \mathrm{l}$.

\section{Gonadotropin Radioimmunoassay}

A carp gonadotropin radioimmunoassay technique was developed similar to the method reported for salmon gonadotropin hormone (Crim et al., 1973). Antisera were produced in male New Zealand white rabbits against relatively pure carp gonadotropin ${ }^{4}$ using the intradermal injection method (Vaiukaitis et al., 1971). Purified carp gonadotropin ${ }^{5}$ suitable for iodination was labeled by the chloramine-T method (Greenwood et al., 1963). Purification of the labeled hormone was conducted just prior to the assay using Biogel P60. All assay incubations were conducted at $4^{\circ}$. Dilute carp gonadotropin antibody $(0.2 \mathrm{ml})$, and sample or standard $(0.1 \mathrm{ml})$ were incubated for $24 \mathrm{hr}$ before the labeled hormone $(0.2 \mathrm{ml})$ was added. Precipitation of antibody-bound labeled hormone was effected using a second antibody system composed of goat antirabbit gamma globulin and normal rabbit serum. Suitability of the assay for goldfish serum and pituitary gonadotropin is indicated by the similarity of dilution curves to carp gonadotropin standards (Fig. 1). Further evidence for assay validation was obtained by comparing the potency of a few goldfish plasma samples in both our assay and a radioimmunoassay for carp GTH previously described by Breton et al., 1972. For plasma samples obtained from a hypophysectomized fish (GTH not detectable) and intact fish, very similar values for gonadotropin were observed (L. Crim and B. Breton, unpublished results).

\footnotetext{
${ }^{4}$ Kindly provided by Dr. Y. A. Fontaine.

5 Kindly provided by Dr. E. Burzawa-Gerard.
} 


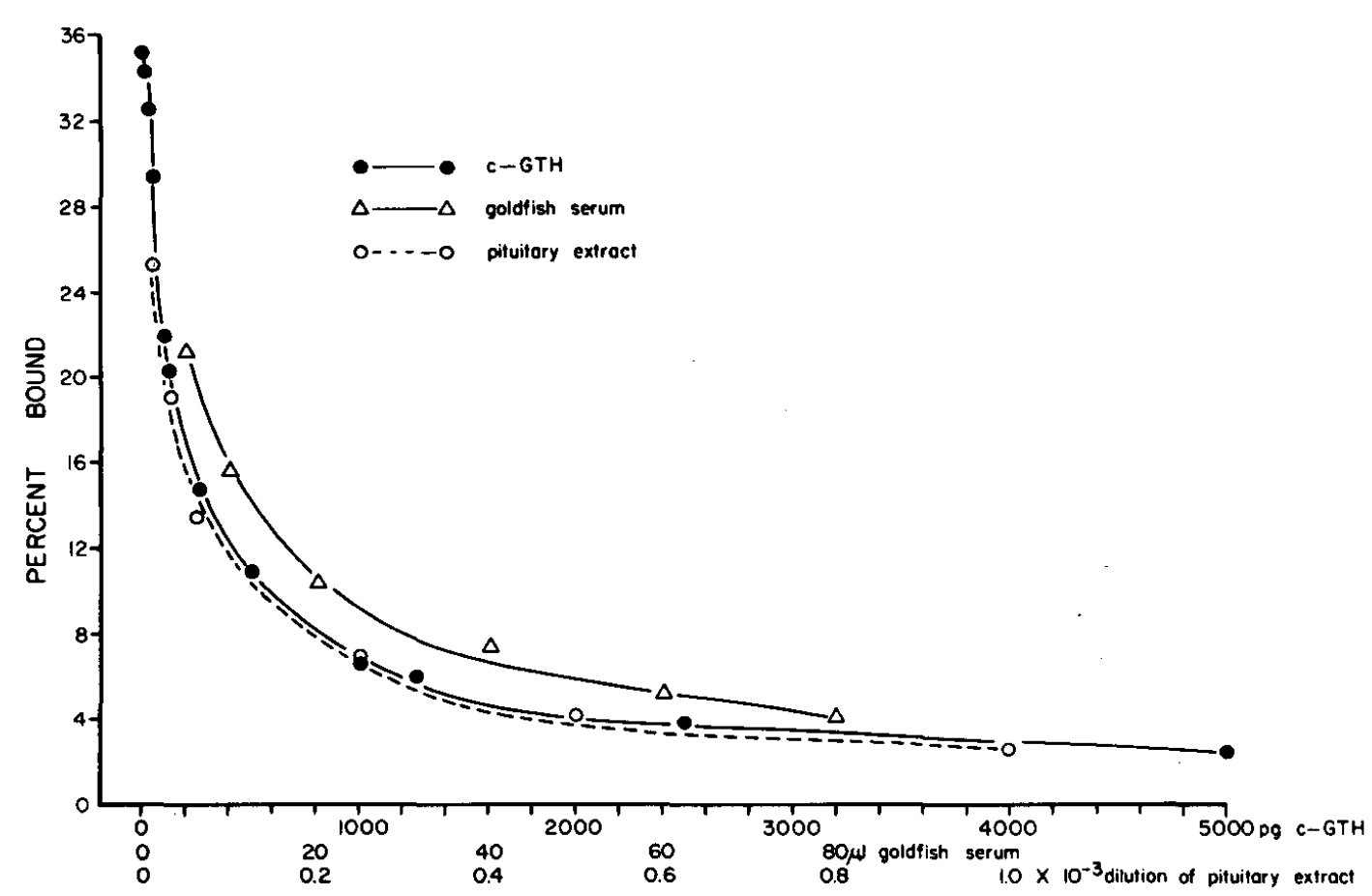

Fig. 1. The immunoreactive dose-response curves for carp and goldfish samples of gonadotropic hormone. Curves of very similar shapes were obtained with dilutions of goldfish serum and crude pituitary extract compared with the carp gonadotropin standard (c-GTH).

Samples were centrifuged, supernatants were aspirated, and the precipitates were counted by gamma scintillation spectrometry. For conditions stated above, $36 \%(\mathrm{~B} / \mathrm{F}=0.56)$ of the labeled carp gonadotropin was bound in the absence of standard hormone. A twofold reduction of $\mathrm{B} / \mathrm{F}$ was achieved with $240 \mathrm{pg}$ of carp gonadotropin.

\section{RESULTS}

Table 1 summarizes the results of the experiment. One value for a fish which ovu- lated during the experiment was eliminated from consideration. Synthetic LH-RH and extract of the lateral lobes of the hypothalamus caused a significant increase in serum gonadotropin concentration. The serum gonadotropin concentration from one of the fish injected with LH-RH was much higher than the others in the LH-RH group and is reported alone in Table 1. Although not shown in the table, this indi-

TABLE 1

EfFects of Third Ventricle Injection of Synthetic LH-RH, and Brain Extracts on SERUM Gonadotropin CONCENTRATIONS IN GOLDFISH

\begin{tabular}{llc}
\hline Material injected & $\begin{array}{c}\text { Gonadotropin } \\
(\mathrm{ng} / \mathrm{ml})\end{array}$ & Significance $^{b}$ \\
\hline Physiological solution & $5.14 \pm 0.90(5)$ & \\
LH-RH & $9.90 \pm 1.10(3)$ & $<0.025$ \\
& $29.0^{c}(1)$ & NS \\
Medial lobe of hypothalamus & $7.52 \pm 2.16(4)$ & $P<0.05$ \\
Lateral lobe of hypothalamus & $8.85 \pm 1.04(4)$ & NS \\
Cerebellum & $5.30 \pm 1.20(3)$ & NS \\
Medulla & $4.70 \pm 1.04(4)$ & \\
\hline
\end{tabular}

a Values are $\bar{x} \pm \mathrm{SE}(N)$

${ }^{b}$ Significance compared to physiological solution injected group.

$c$ See text for explanation. 
vidual value lies outside the $95 \%$ confidence interval of the PS injected control group $(5.14 \pm 2.50 \mathrm{ng} / \mathrm{ml})$. There were no significant differences between the PS injected control group and the groups injected with either extract of the medial lobe of the hypothalamus, cerebellum, or medulla, although some elevation in the serum gonadotropin concentration did occur in the animals injected with extract of the medial lobe of the hypothalamus.

The gonadotropin content of the $50-\mu 1$ samples of crude tissue extract was as follows: medial lobe of hypothalamus, $78 \mathrm{pg}$; lateral lobes of hypothalamus, $198 \mathrm{pg}$; cerebellum, $285 \mathrm{pg}$; and medulla, $410 \mathrm{pg}$.

\section{DISCUSSION}

Intraventricular infusion of $\mathrm{LH}-\mathrm{RH}$ stimulates release of gonadotropin in mammals. Specifically, luteinizing hormone (LH) levels rise after intraventricular LH-RH treatment of rabbits (Baldwin et al., 1974) and rats (Weiner et al., 1972; Ondo et al., 1973; Ben-Jonathan et al., 1974). The iv administration of LH-RH in the rat causes a sharp peak in $\mathrm{LH}$ release, whereas injection via the intraventricular route causes a more prolonged rise and may therefore be the more "sensitive" route of administration (Ben-Jonathan et al., 1974). The ependymal cells lining the third ventricle in the region of the median eminence probably play a role in the transfer of LH-RH from the cerebrospinal fluid to the portal vessels in the mouse (Zimmerman $e t$ al., 1974).

The fact that fish respond to iv treatment with $\mathrm{LH}-\mathrm{RH}$ by a rise in gonadotropin secretion has been previously shown using carp (Breton and Weil, 1973; Weil et al., 1975) and trout (Crim and Cluett, 1974). In the present study, stimulation of gonadotropin secretion was observed after LH-RH infusion into the third ventricle of goldfish. The magnitude of the response observed here is similar to that reported by
Crim and Cluett (1974) and Weil et al. (1975), but less than that described by Breton and Weil (1973). However, since the time course of the response was not followed in the present work, it is possible that a higher serum gonadotropin concentration could have occurred at some time other than the 20 -min postinfusion sampling time. Weil et al. (1975) have shown that the carp is most responsive to $\mathrm{LH}-\mathrm{RH}$ during its reproductive season. Although sexually mature fish were used in the present work, as well as by Breton and Weil (1973) and Crim and Cluett (1974), the response differences between the various experiments may also be in part explained by dosage differences, route of administration, species differences, and temperature conditions of the experiments.

Stimulation of gonadotropin secretion was observed following injections of goldfish hypothalamic extract into the third ventricle. This confirms previous studies (see the introduction) showing GRH in teleost hypothalamic extracts. In the present study the GRH appeared to be localized to the hypothalamic tissue, since extracts of the cerebellum and medulla were ineffective. Because the variability of the gonadotropic response for goldfish receiving medial lobe hypothalamus extract was relatively enlarged (note also the least amount of tissue was used to prepare this extract), no conclusive statement can be made from this study regarding distribution of GRH within the goldfish hypothalamus. However, lesion studies of goldfish provide indirect evidence for GRH in the medial lobe of the hypothalamus (Peter, 1970). The GRH activity of the hypothalamic extracts cannot be attributed to a gonadotropin hormone in the extracts, since the medulla and cerebellum extracts each had a larger amount of immunoreactive gonadotropin than either of the hypothalamic extracts, but yet did not have an effect on serum gonadotropin levels. Finding low levels of 
GTH in goldfish brain tissue extracts is of interest; however, from the GTH values found in serum it appears this could be explained by contamination of the extracts with blood.

The presence of releasing hormone-like substances in hypothalamic tissue of lower vertebrates has been examined using radioimmunoassay procedures. No evidence for substances immunologically related to synthetic $\mathrm{LH}-\mathrm{RH}$ was found in extracts of the goldfish hypothalamus or anterior and posterior portions of the pituitary gland (Deery, 1974). Thus, the identity of the teleost GRH is open. In contrast, a general distribution of thyrotropin releasing hormone-like activity has been found in the hypothalamus throughout the vertebrate kingdom (Jackson and Reichlin, 1974; R. E. Peter and R. D. Utiger, unpublished results).

\section{ACKNOWLEDGMENTS}

We wish to thank Miss E. A. Monckton for her very able technical assistance. The visit by $R$. Billard to the University of Alberta was made possible by an exchange fellowship between the National Research Council of Canada and Centre National de la Recherche Scientifique of France.

This is M.S.R.L. Contribution No. 228.

\section{REFERENCES}

Baldwin, D. M., Haun, C. K., and Sawyer, C. H. (1974). Effects of intraventricular infusions of $\mathrm{ACTH}^{1-24}$ and $\mathrm{ACTH}^{4-10}$ on $\mathrm{LH}$ release, ovulation and behavior in the rabbit. Brain Res. 80, 291301.

Ben-Jonathan, N., Mical, R. S., and Porter, J. C. (1974). Transport of LRF from CSF to hypophysial portal and systemic blood and the release of LH. Endocrinology 95, 18-25.

Breton, B., Jalabert, B., and Weil, C. (1975). Caracterisation partielle d'un facteur hypothalamique de liberation des hormones gonadotropes chez la carpe (Cyprinus carpio L.) etude in vitro. Gen. Comp. Endocrinol. 25, 405-415.

Breton, B., and Weil, C. (1973). Effets du LH/FSHRH synthetique et d'extraits hypothalamiques de carpe sur la secretion d'hormones gonadotrope in vivo chez la carpe (Cyprinus carpio L.). C.R. Acad. Sci., Ser. D 277, 2061-2064.

Breton, B., Billard, R., Jalabert, B., and Kann, G. (1972). Dosage radioimmunologique des gonadotropins plasmatiques chez Carassius auratus, aur cours du nycthemese et pendant l'ovulation. Gen. Comp. Endocrinol. 18, 463-468.

Breton, B., Weil, C., Jalabert, B., and Billard, R. (1972). Activite reciproque des facteurs hypothalamiques de belier (Ovis aries) et de poissons teleosteens sur la secretion in vitro des hormones gonadotropes $\mathrm{c}-\mathrm{HG}$ et $\mathrm{LH}$ respectivement par des hypophyses de carpe et de belier. C.R. Acad. Sci., Ser. D 274, 2530-2533.

Crim, L. W., and Cluett, D. M. (1974). Elevation of plasma gonadotropin concentration in response to mammalian gonadotropin releasing hormone treatment of the male brown trout as determined by radioimmunoassay. Endocrinol. Res. Comm. 1, 101-110.

Crim, L. W., Meyer, R. K., Donaldson, E. M. (1973). Radioimmunoassay estimates of plasma gonadotropin levels in the spawning pink salmon. Gen. Comp. Endocrinol. 21, 69-76.

Deery, D. J. (1974). Determination by radioimmunoassay of the luteinizing hormone-releasing hormone (LHRH) content of the hypothalamus of the rat and some lower vertebrates. Gen. Comp. Endocrinol. 24, 280-285.

Greenwood, F. C., Hunter, W. M., and Glover, J. G. (1963). The preparation of ${ }^{131}$ I-labelled human growth hormone of high specific radioactivity. Biochem. J. 89, 114-123.

Jackson, I., and Reichlin, S. (1974). Thyrotropinreleasing hormone (TRH): Distribution in hypothalamic and extrahypothalamic brain tissues of mammalian and submammalian chordates. Endocrinology 95, 854-862.

Ondo, J. G., Eskay, R. L., Mical, R. S., and Porter, J. C. (1973). Release of LH by LRF injected into the CSF: A transport role for the median eminence. Endocrinology 93, 231-237.

Peter, R. E. (1970). Hypothalamic control of thyroid gland activity and gonadal activity in the goldfish, Carassius auratus. Gen. Comp. Endocrinol. 14, 334-356.

Peter, R. E., and Billard, R. (1976). Effects of third ventricle injection of prostaglandins on gonadotropin secretion in goldfish, Carassius auratus. Gen. Comp. Endocrinol. In press.

Peter, R. E., and Gill, V. E. (1975). A stereotaxic atlas and technique for forebrain nuclei of the goldfish, Carassius auratus. J. Comp. Neurol. 159, 69-102.

Vaitukaitis, J. C., Robbins, J. B., Nieschlag, E., and Ross, G. T. (1971). A method for producing specific antisera with small doses of immunogen. $J$. Clin. Endocrinol. Metab. 33, 988-991. 
Weil, C., Breton, B., and Reinaud, P. (1975). Etude de la réponse hypophysaire à l'administration de Gn-RH exogène au cours du cycle reproducteur annuel chez la carpe Cyprinus carpio L. C.R. Acad. Sci. 280D, 2469-2472.

Weiner, R. I., Terkel, J., Blake, C. A., Schally, A. V., and Sawyer, C. H. (1972). Changes in serum luteinizing hormone following intraven- tricular and intravenous injections of luteinizing hormone-releasing hormone in the rat. Neuroendocrinology 10, 261-272.

Zimmerman, E. A., Hsu, K. C., Ferin, M., and Kozlowski, G. P. (1974). Localization of gonadotropin-releasing hormone ( $\mathrm{Gn}-\mathrm{RH})$ in the hypothalamus of the mouse by immuno-peroxidase technique. Endocrinology 95, 1-8. 